Wind \& Hydropower Technologies Program

Harnessing America's abundant natural

resources for clean power generation

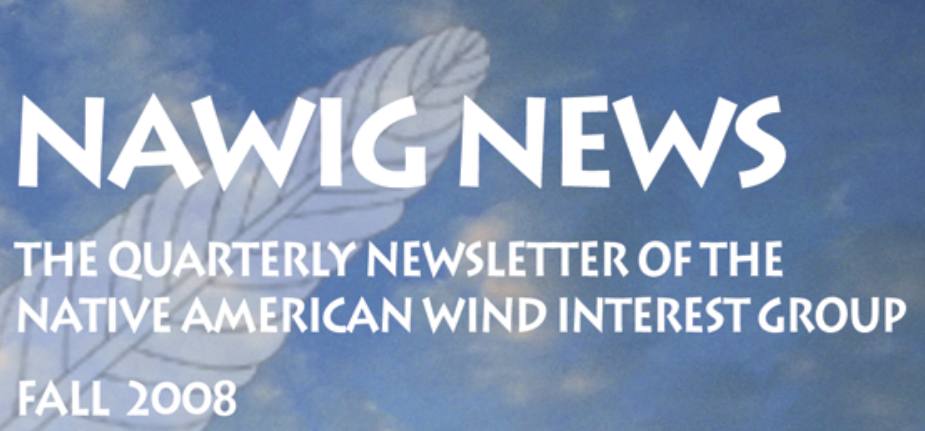

ב

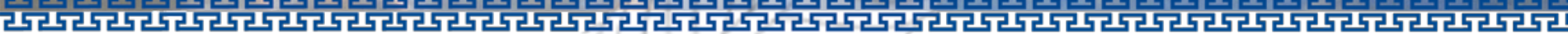

\begin{abstract}
As part of its Native American outreach, DOE's Wind Powering America program has initiated a quarterly NAWIG newsletter to present Native American wind information, including projects, interviews with pioneers, issues, WPA activities, and related events. It is our hope that this newsletter will both inform and elicit comments and input on wind development in Indian Country.
\end{abstract}

\section{Using the Power of the Wind}

An Interview with Dave Danz

Dave Danz has been a tribal planner since 1978 and a planner with the Grand Portage Band of Chippewa in northeast Minnesota since 2006. He is, as he puts it, "A white guy in Indian Country with no background in wind energy." Until recently, that is.

A Minnesota Department of Commerce study concluded that the north shore of Lake Superior did not have a wind resource capable of generating electricity. To the folks who lived in the area, that finding seemed counterintuitive.

We'll let Dave pick up the story from there.

How did you become interested in wind development?

Dr. Michael Mageau, assistant professor of environmental studies at the University of Minnesota Duluth and director of the Center for Sustainable Community Development (CSCD), decided to determine the validity of the state of Minnesota's study. In January 2004, CSCD and Grand Portage staff mounted an anemometer and a data recorder at 20 meters on the fire lookout tower at Mount Maude, elevation 1,754 feet. Although not ideal-wind data is more reliable at heights of at least 50 meters above the groundthe study indicated that a 1.5- to 2-megawatt (MW) wind energy project was viable on the Grand Portage reservation. In 2006, I attended the Wind Energy Applications Training Symposium (WEATS) organized by the National Renewable

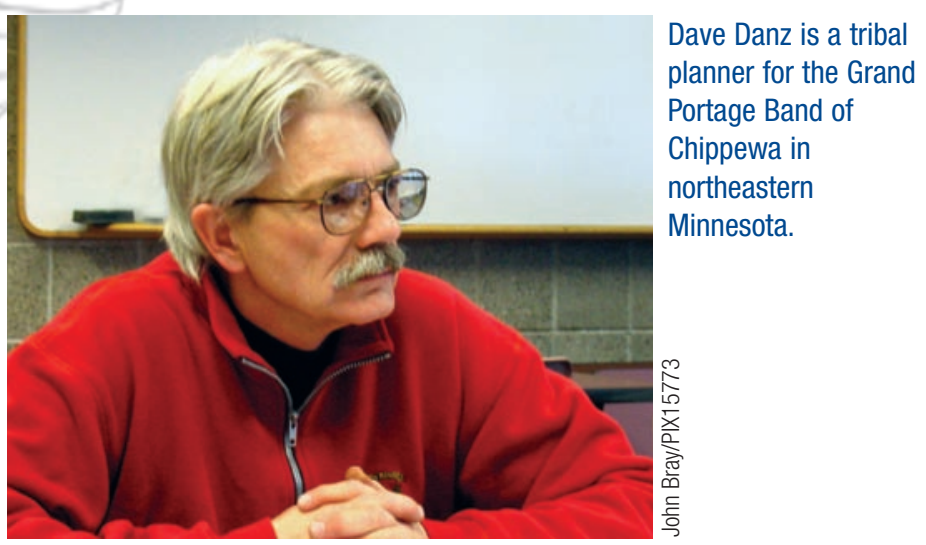

Energy Laboratory (NREL). WEATS is an opportunity to observe large and small wind systems in operation in the field, meet with leaders in the U.S. wind energy industry, and get acquainted with Native American tribal citizens and attendees from other countries.

Among many other valuable things, I learned that NREL has an anemometer loan program through which the tribe could borrow equipment capable of gathering accurate and comprehensive wind data. We hired Northern States Tower Service to install the equipment in January 2007. This time, the anemometers were mounted at 30, 50, and 80 meters off the ground on TV towers on Mount Maude.

The data indicate that we have average wind speeds of about 18 miles an hour-an excellent wind resource. In fact, it's possible that the site could produce up to $50 \mathrm{MW}$, and it takes just $1 \mathrm{MW}$ to run the village of Grand Portage.

What are the steps a tribe and its partners must take in developing a wind project?

First, they must analyze the potential sites for the installation. Some of the questions they might ask include: Who owns the land? Is it accessible? Is the project politically and spiritually acceptable to the tribe?

Next, the wind development team should conduct a detailed wind assessment. I encourage tribes to take 
- Story continued from front page

advantage of the NREL WEATS training and anemometer loan program to help reduce the costs of assessing their wind resource.

Once they are confident that they have a wind resource worth developing, the team must secure the site, negotiate or execute leases, establish rights-of-way, etc. They must also perform a transmission interconnection study to establish how they will distribute the power from the turbines to the utility grid and develop power purchase agreements with the entities that will buy the electricity the turbines produce.

Before construction can begin, the team will also have to conduct an environmental assessment at the site and obtain the necessary permits. In addition, engineering reports and construction cost estimates are necessary to secure financing. Other tasks include selecting turbines and negotiating agreements with vendors, arranging financing, attracting investors, and working out development/ownership/management agreements. And after construction of the wind energy facility is completed, there are ongoing operation and maintenance tasks.

Throughout this process, it is critical that everyone involved focus on protecting tribal interests. Wind development can be an economic boon to a tribe if all the participants share that value from the beginning.

Although all of this sounds pretty daunting, there are organizations that help tribes work through the process.

Where is the Grand Portage Band in this process?

We are in talks with Citizens Energy about helping us develop a wind project. We are also working on access to transmission lines, and have assessments to do at different sites to ensure that the wind resource is consistent.

What are the biggest challenges to getting wind energy projects installed on native lands and under native ownership?

At the beginning, the challenges for a tribe are typically internal. The first step is educating people so that they understand the benefits-both economic and environmental-of generating electricity from the wind. Then the tribe must find partners who can help complete each of the steps cited above.

For us, the WEATS training was critical, and NREL's anemometer loan was significant. Knowing that we had reliable technical resources to call on helped to move the process along and reduce our anxiety level about taking on such a big project. The contacts we made at WEATS were invaluable.

What is the timeline for the Grand Portage project?

We are still a couple of years out from getting investors in on a project. As an initial effort, it seems that a 1- to 2-MW project is probably manageable from the tribe's perspective.

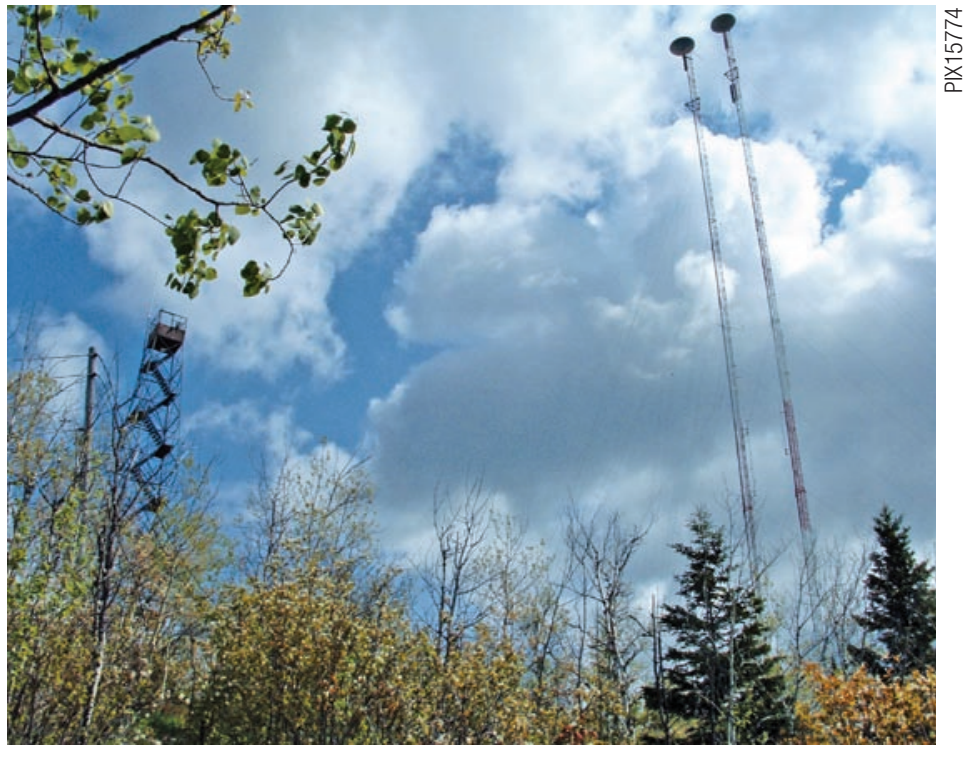

The first anemometer on Mount Maude on the Grand Portage Chippewa reservation in northeast Minnesota was mounted at 20 meters on the fire lookout (left) in January 2004. In January 2007, anemometers were mounted at 30,50 , and 80 meters off the ground on TV towers on Mount Maude (right).

\section{How are these projects financed?}

One of the real deficiencies in U.S. energy policy is the lack of funding for clean energy projects. The benefits of these projects for all concerned would seem to argue for more robust funding opportunities. This is particularly true for resource assessment and feasibility studies.

Can other tribal citizens interested in exploring the possibility of developing their own wind resources contact you?

Sure. Using the wind to supply energy for use in our daily lives does not require sending young warriors to foreign lands or make permanent scars on the land. Nor does it offend gichi-manidoo, the Great Spirit. We encourage other tribal citizens to learn about minwaabaji noodi, "getting use of the power of wind." They can contact me using the information below.

Dave Danz is a tribal planner with the Grand Portage Band of Chippewa. You can reach him at 218.475.2844 or dave.danz@gmail.com.

\section{Resources}

\author{
National Renewable Energy Laboratory \\ Anemometer Loan Program \\ Wind Energy Applications Training Symposium (WEATS) \\ Tony Jimenez \\ National Renewable Energy Laboratory \\ 303.384.7027 \\ tony_jimenez@nrel.gov
}

Citizens Energy Corporation

Tod Hynes, Director of Alternative Energy

617.951.0477

thynes@citizensenergy.com 


\section{Lakota Nation Installs 65-kW Wind Turbine}

On the 132nd anniversary of the Little Big Horn, the Lakota celebrated a new wind turbine installation: a $65-\mathrm{kW}$ Nordtank turbine on the edge of Porcupine Butte that supplies 120 megawatt-hours of wind power to KILI, the Pine Ridge Reservation radio station known as the Voice of the Lakota Nation.

The 100,000-watt KILI is the most powerful radio station in Indian Country and has an electricity demand to prove it. The new turbine installation is expected to provide the station with $\$ 12,000$ a year in electricity savings at today's energy prices, with increased savings in the following years. This savings represents four times the average annual income on a reservation with up to $80 \%$ unemployment. Surplus power will be sold to the local utility, further reducing the station's energy costs.

According to KILI station manager Melanie Janis, the Lakota Nation wind project is a major step in fulfilling the station's 25 -year dream of being fully powered by renewable energy. The community project is the result of a broad collaboration of federal, tribal, and local wind energy advocates, including the fundraising efforts of Honor the Earth, an American Indian nonprofit group that supports environmental activism and sustainability in Native communities.

The turbine hardware and installation cost about $\$ 150,000$, an amount equal to KILI's annual budget for the $24 / 7$ programming of music, news, meetings, and community information. Support from the Department of the Interior's (DOI's) Office of Indian Energy and Economic Development included $\$ 50,000$ for the turbine, along with $\$ 106,000$ for tribal training, documentation, and curriculum development as part of the DOI's initiative to encourage economic development in Indian Country. Critical funding was also obtained from the sale of the project's green tags to NativeEnergy, a carbon offset retailer that focuses on developing tribal renewable energy projects.

The Intertribal Council On Utility Policy (COUP) provided technical assistance for the refurbished turbine project and classroom training sessions on the Rosebud and Pine Ridge Reservations for COUP tribal members interested in learning the basics of wind development, foundation construction, and turbine installation, repair, and maintenance. The 2-week training program was originally developed in anticipation of the Rosebud Sioux Tribe's 30- to 60-MW Owl Feather War Bonnet project on a site south of St. Francis on the Rosebud Reservation. Approximately 75 tribal members participated in the hands-on and classroom training conducted on the two reservations, geared toward encouraging tribal employment in the upcoming wind projects and featuring experts from NREL and private engineering and consulting firms working in Indian Country.

Work began 6 years ago when the National Renewable Energy Laboratory's (NREL's) Wind Powering America (WPA) program erected a 20-m anemometer on the west side of Porcupine Butte in the shadow of the radio station.
WPA team members analyzed the data to confirm a wind resource in excess of $13 \mathrm{mph}$ at 20 meters. KILI is located in an area with wind speeds in excess of 18 miles per hour at 50 meters.

The project experienced delays. First, the station required new broadcasting equipment to continue airing its programming. Then lightning struck the station's 509-foot antenna. Delays in passing federal budgets postponed project funding twice, and there were difficulties obtaining an appropriately sized turbine at an affordable price.

The 65-kW turbine will reduce some, and sometimes all, of KILI's electricity needs, according to Claud Matney of Matney-Franz, the Montana engineering firm coordinating the project. The project is not net metered, but any surplus power generated by the turbine will be sold directly to the local rural utility, as per the interconnection agreement with LaCreek Rural Electric Cooperative, headquartered in Martin, South Dakota.

KILI is now a community wind power leader, joining the ranks of dedicated community wind projects that reduce energy costs, carbon emissions, and global warming. As the KILI Web site proclaims: "Amidst all the poverty and despair here on the Pine Ridge Reservation, KILI is a ray of hope and a tool of change for our people who are struggling to build new, healthy, and productive futures."

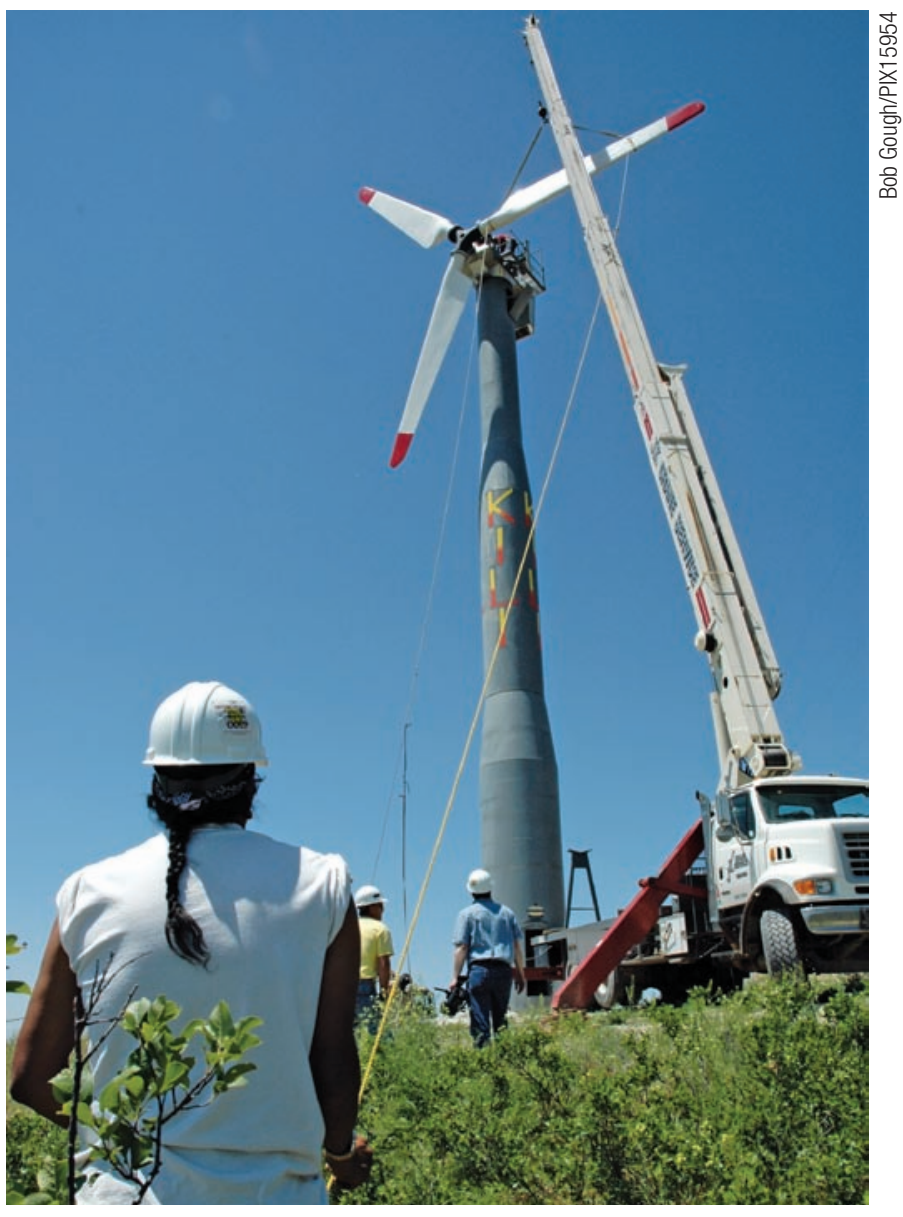

Workers attach the blades of a refurbished wind turbine that will be used to power the KILI radio station at the Pine Ridge Reservation in South Dakota. 
NAWIG Events 2008 Calendar

October $29-30,2008$

AWEA Wind Power Health \& Safety Workshop - Denver, CO www.awea.org/events/

January $25-27,2009$

Harvesting Clean Energy Conference - Billings, MT

www.harvestcleanenergy.org

February $24-25,2009$

AWEA Wind Power Project Siting Workshop - Seattle, WA www.awea.org/events/

March 17 - 18, 2009

AWEA Wind \& Transmission Workshop - Overland Park, KS www.awea.org/events/

May $4-7,2009$

WINDPOWER 2009 Conference \& Exhibition - Chicago, IL

www.awea.org/events/
October $11-16,2009$

66th Annual Convention of the National Congress of American

Indians - Palm Springs, CA
Wind Powering America • www.windpoweringamerica.gov

American Wind Energy Association • www.awea.org

U.S. Department of Energy Tribal Energy Program •

www.eere.energy.gov/tribalenergy

National Wind Coordinating Committee $\bullet$ www.nationalwind.org
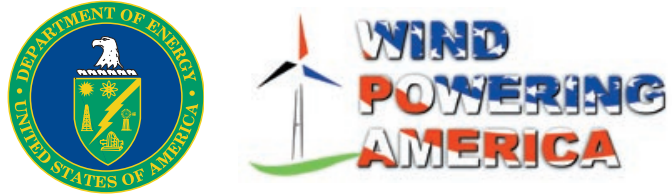

Prepared for the U.S. Department of Energy

by the National Renewable Energy Laboratory, a DOE National Laboratory
For more information contact:

EERE Information Center

1-877-EERE-INF (1-877-337-3463)

www.eere.energy.gov

\section{A Strong Energy Portfolio for a Strong America}

Energy efficiency and clean, renewable energy will mean a stronger economy, a cleaner environment, and greater energy independence for America. Working with a wide array of state, community, industry, and university partners, the U.S. Department of Energy's Office of Energy Efficiency and Renewable Energy invests in a diverse portfolio of energy technologies.

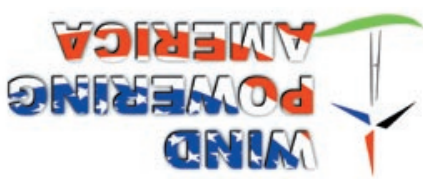

